\title{
THE INFLUENCE OF PAPAIN AND BROMELAIN ENZYMES ON HATCHING RATE AND HATCHABILITY OF (OREOCHROMIS NILOTICUS) EGGS
}

\author{
Fariedah Fani ${ }^{\star}$, Widodo Maheno Sri \\ Study Program of Aquaculture, Department of Fisheries Resources Utilization, \\ Faculty of Fisheries and Marine Science, University of Brawijaya, Indonesia \\ *E-mail: fanifariedah@ub.ac.id
}

\begin{abstract}
Tilapia is a mouth breeder fish where these fish incubate and care for fish larvae in the mother's mouth until 12 days. In this process tilapia will fast until the egg in the mouth hatches and can find its own food. This had an effect on the availability of seeds on the market and also impacts on parent conditions because it is undergoing a period of incubation so that it will prolong the recovery period after spawning. This study aims to determine the effect of papain and bromelain enzymes in tilapia hatching on the hatching rate and hatching duration of tilapia that are carried out outside the parent's mouth. This research was started from artificial spawning on the parent of Tilapia and took the eggs of Tilapia fish in the mouth of the female parent to be transferred into a recirculation container. The eggs that have been transferred to recirculation containers are given exposure to the papain and bromelain enzymes to help trigger the hatching process. The experimental method was factorial completely randomized design with the first factor being the enzyme and the second factor was the enzyme dose with three replications. The main parameters are hatching rate, hatching duration, and survival rate. The results showed that the highest hatching success rate using the papain enzyme was obtained at a dose of 0.15 micromole of $73.33 \%$, whereas when using the bromelain enzyme at a dose of 0.12 micromole of $68.89 \%$. Tilapia eggs can hatch faster than tilapia eggs without treatment. The highest survival rate using the papain enzyme was achieved at a dose of 0.15 with a value of $78.89 \%$ while those using the bromelain enzyme were obtained at a dose of 0.12 of $86.94 \%$.
\end{abstract}

\section{KEY WORDS}

Papain enzyme, bromelain enzyme, Oreochromis niloticus, mouthbreeder.

Tilapia (Oreochromis niloticus) is one of the most widely cultivated freshwater fish in Indonesia. Tilapia is also an important fish in aquaculture. Tilapia is an important fish in the world because tilapia consumers are found on various continents. Red tilapia is even used as a substitution (substitute) for red snapper (Sea bream) because of its similar appearance; therefore, tilapia is referred to as freshwater snapper (Ghufran and Kordi, 2010).

Factors that play an important role in the prospect of tilapia are the distinctive taste of the meat, the clean white color of the meat and the high nutritional content, so that it is often used as a source of protein that is cheap and easy to obtain, and has an affordable selling price by the community (Aliyas and Ya'la, 2016).

Tilapia is a mouthbreeder fish where these fish incubates and cares for fish larvae in the mother's mouth. Females incubate eggs in the mouth to protect from predators so that the eggs can hatch perfectly. Tilapia incubates their eggs until 12 days at the age of 6-7 days after hatching larva begins to be released by the mother. In this process, tilapia will fast until the egg in the mouth hatches and can find its own food. Fasting mothers will lead to weight loss and are susceptible to disease (Santoso, 1996).

Based on the test results of the protease enzyme content in the mouth of tilapia that are incubating eggs found that in the saliva of tilapia there was a protease enzyme content of $0.09 \mu \mathrm{mol}$. The temperature in the water that is in the mouth of tilapia is the same as the ambient temperature because the fish has poikilothermic properties, that is, the body temperature adjusts to the ambient temperature. 
Protease enzyme is enzymes that function to break down proteins by hydrolyzing peptide bonds to amino acids in the polypeptide chain. According to Masniar, et al., (2016) that bromelain enzyme is one group of protease enzymes where the bromelain enzyme has the ability to hydrolyze peptide bonds to proteins or polypeptides into smaller molecules, amino acids. Bromelain enzyme is obtained from pineapple extract. Hamza (2017) declared that papain is a form of the protease enzyme sourced from fruits other than bromelain from pineapple.

This study aims to determine the effect of different dosage of papain and bromelain enzymes in hatching tilapia on the hatchability of tilapia eggs. In order to get the best dose of papain and bromelain enzyme used in hatching tilapia eggs.

\section{MATERIALS AND METHODS OF RESEARCH}

The tools used for research include: Microscopes, Aquariums, Aerators, T Pipes, L Pipes, hoses, clear plastic bottles, roll cords, pH pens, Hg thermometers, DO meters, hand tally counter, spuit, drop pipes, water pumps, shelves, cameras, happa, film bottles, jars, heaters. The materials used for the study are as follows: 6 month old Tilapia fish, Tilapia fish eggs, detergent and foam, papain, bromelain, black plastic, freshwater, aquades, Glue, Label paper, tissue, rubber, napkin, trash bag.

The research method uses factorial completely randomized design using enzyme as the first factor and enzyme dosage as the second factor. Each treatment was repeated three times. Research preparation begins with preparing and cleaning the research container. Research containers used $10 \mathrm{~L}$ jars and incubators. The jar was washed using detergent and then dried for 24 hours. Hatching tilapia eggs used a hatching incubator. The incubator for hatching tilapia eggs was made from 2 bottles of $1.5 \mathrm{~L}$ mineral water combined into one. In the middle, a pipe with a length of $30 \mathrm{~cm}$ and a meter of $1.5 \mathrm{~cm}$ is given. The pipe in the middle of the incubator is connected to the water pump so that water from the jar can be flowed into the incubator. So the water recirculation process occurs between the water in the incubation with the water in the jar.

The media used in this study is clean freshwater that had been deposited for 24 hours. The deposition process was carried out to remove parasites in the water. After being deposited water was given a treatment in the form of a commercial bromelain enzyme which aims to increase the time of hatching of eggs. The dosage used in this study was the papain and bromelain enzyme with 0.06 and 0.09 micromoles and control. In this study, 3 repetitions were carried out in order to get accurate data.

The sample used in this study was tilapia eggs. Tilapia eggs were collected from the mouths of tilapia that have spawned. The steps taken to take tilapia eggs were as follows:

- Tilapia that has spawned in the pond were checked;

- Water in the spawning pond was drained if there were fish which incubate their eggs in their mouth;

- Fish which incubate eggs was taken and the eggs were taken out from their mouth.

One of the main parameters is the success of hatching eggs in tilapia (Oreochromis niloticus) or hatching rate. Egg hatchability is the percentage of eggs that mature after the eggs are fertilized. According to Effendi (2002), hatching rate is number of eggs that hatched divided by the number of fertilized eggs multiplied by 100 percent.

The other main parameter is the hatching time of tilapia eggs, said to be an indicator of the success of the study because it is able to prove that the addition of enzymes can accelerate the hatching time of incubated eggs in the hatching container. In addition, observing the hatching time can find out how much influence the addition of enzymes to the erosion of egg shells.

\section{RESULTS AND DISCUSSION}

The hatching of eggs is the last phase of the development of egg embryogenesis. The egg is said to hatch when an embryo that has developed perfectly and comes out of the 
egg shell. This is due to mechanical movements and enzymatic reactions that occur in the egg. Kossakowski (2012) stated that hatching process is characterized because of the join effect of the hatching enzyme (chorionase) delivered by hatching gland cells and mechanical damage of egg envelope. The results of research that have been carried out get the value of hatchability of tilapia eggs in each treatment are in Table 1.

Table 1 - Hatching Rate of $O$. niloticus

\begin{tabular}{|c|c|c|c|c|c|c|}
\hline \multirow{2}{*}{ Enzyme } & \multirow{2}{*}{ Dose (micromole) } & \multicolumn{3}{|c|}{ Replication } & \multirow{2}{*}{ Total } & \multirow{2}{*}{ Average } \\
\hline & & 1 & 2 & 3 & & \\
\hline \multirow{3}{*}{ Papain } & 0,12 & 66.67 & 56.67 & 56.67 & 180.01 & 60.00 \\
\hline & 0,15 & 73.33 & 56.67 & 56.67 & 186.67 & 62.22 \\
\hline & 0,18 & 50 & 63.33 & 53.33 & 166.66 & 55.55 \\
\hline \multirow{3}{*}{ Bromelain } & 0,12 & 63.33 & 73.33 & 70 & 206.66 & 68.89 \\
\hline & 0,15 & 53.33 & 53.33 & 60 & 166.66 & 55.55 \\
\hline & 0,18 & 60 & 56.67 & 60 & 176.67 & 58.89 \\
\hline Total & & & & & 1083.33 & \\
\hline
\end{tabular}

Table 1 described the relationship of hatchability with the addition of the enzyme bromelain and papain with different dosage. The lowest hatching rate was found in 0,18 micromoles with an egg hatching value of $55.55 \%$ from enzyme papain treatment with different dosage, while the highest value was obtained at the treatment dose of 0,15 micromoles of $62,22 \%$. Different result was depicted from the addition bromelain enzyme treatment, the lowest hatching rate $(55.55 \%)$ was resulted from 0,15 micromoles. Graph data on the average hatchability of tilapia eggs with the addition of the enzyme bromelain and papain with different dosage is shown in Figure 1.

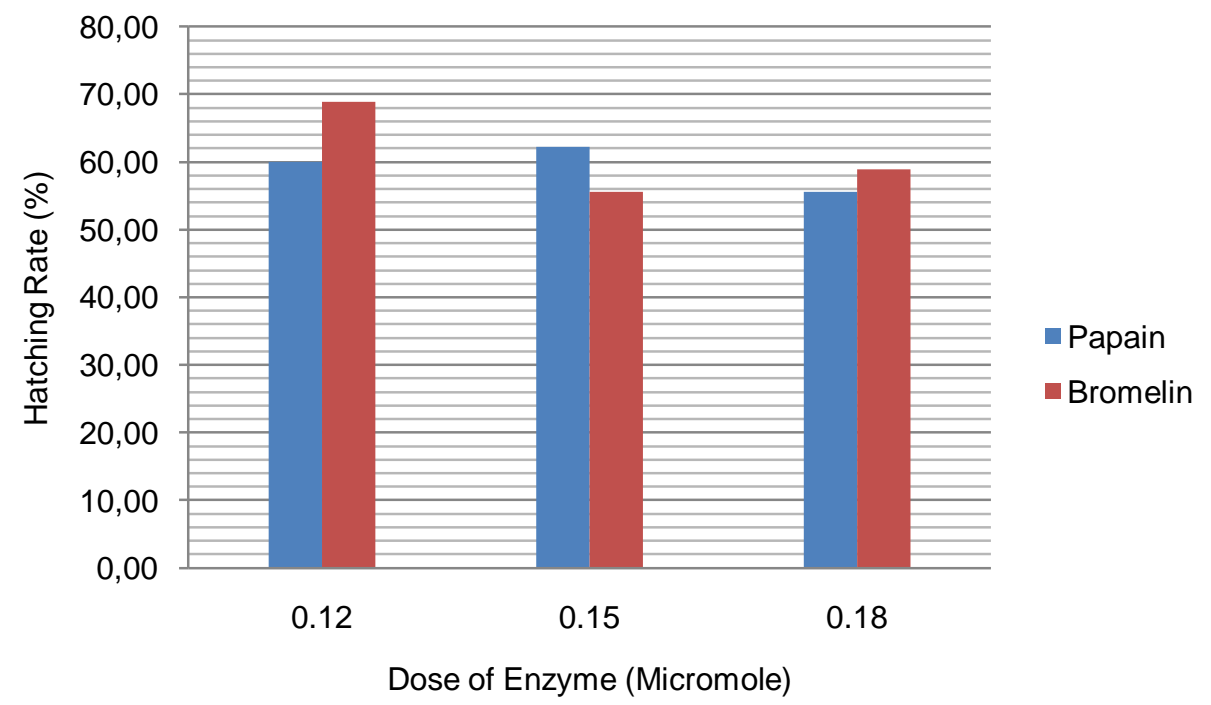

Figure 1 - Hatching rate of $O$. niloticus Graph

Figure 1 illustrated that average value of hatching rate of tilapia eggs with addition of the enzyme bromelain and papain affects the hatchability of tilapia eggs. This is in accordance with Linhart et al., (2003), the use of proteolytic enzymes can significantly increase hatching and shorten the hatching time. However, the amount of enzyme content that is too high will damage the outside and reduce the hatchability of eggs. According to Saputra et al. (2012), damage to the outer layer of the egg (chorion) can be caused by the high content of the enzyme bromelain contained in the treatment solution. According to Haser et al. (2018) giving large concentrations will cause damage to the enzyme so that the work of the hatching enzyme is disrupted which can hinder the process of hatching eggs so that it causes abnormalities in fish larvae. In addition, according to Mukti et al., (2009) the 
outermost layer of hardened eggs causes the embryo will be difficult to get out, after the outermost layer of the egg breaks the embryo will come out in an abnormal body condition.

The data obtained were analyzed by the variance test found that the dosage and combination treatment affected the hatching rate, while the enzyme did not affect the hatching rate of tilapia eggs. It can be concluded that the different enzyme treatments did not affect the hatching rate of tilapia eggs.

The results of observations on the hatch duration of tilapia eggs that had treated with the papain and bromelain enzymes showed that tilapia eggs hatched after 83 hours from fertilization. This time was faster than the hatch duration tilapia eggs without using the enzyme bromelain. As a question from Haser et al., (2018) which states that the best concentration to increase hatchability and reduce larval abnormalities is at a concentration of $4 \mathrm{ml}$ of crude proteolytic enzymes. This is caused by proteolytic enzymes so the growth of embryos can increase.

According to Linhart et al. (2003), the use of proteolytic enzymes can significantly increase hatching and shorten the hatching time. On the other side, high enzyme dosage will damage the outside and reduce the hatchability of eggs. This is in accordance with the statement Saputra et.al (2012), destruction the outer layer of the egg (chorion) can be caused by the high content of the enzyme bromelain contained in the treatment solution.

The hatching process generally takes place faster at higher temperatures because at high temperatures the metabolic process goes faster so embryo development will be faster which results in more intensive movement of embryos in the shell. However, temperatures that are too high or change suddenly can hinder the hatching process and cause death. Optimal temperature for fish hatching is $27-30^{\circ} \mathrm{C}$. The effect of temperature fluctuation also affects the acclimation process, especially in fish species (Kayhan and Belgin, 2010).

This is confirmed with the statement of Soviawati, (2004) which states that at low temperatures chemical reactions (which use enzyme catalysts) take place slowly and at high temperatures chemical reactions take place quickly, in other words hatching process occurs due to enzymatic action, namely enzymes and other chemicals released by the endodermal gland in the pharynx region of the embryo or an enzyme called chorionase whose action is to reduce the chorion consisting of pseudokeratine to become soft, so that the thin and exposed part of the chorionase will rupture and the embryo's tail comes out of the shell then followed by the body and head.

The results of this relationship can be concluded that the two enzymes have different abilities, but at the smallest dose it is known that hatching process runs slower than the other dosage. In papain enzyme treatment $A$ with a dose level of $0.12 \mu \mathrm{mol}$ has a hatching rate $60.003 \%$, while on bromelain with a dose of $0.12 \mu \mathrm{mol}$ gets the best HR treatment of $68.87 \%$. The fastest hatching time in the two enzymes was obtained in treatment $\mathrm{C}$ which was $0.18 \mu \mathrm{mol}$.

That statement explains that the ability of each enzyme to help the hatching process is determined by the dose level. The more dosage given, the faster it hatches, but does not guarantee a maximum hatching rate. This statement is supported by previous research Saputra et al., (2012), damage to the outer layer of the egg (chorion) caused by the sharpness of the enzyme solution can damage the egg and interfere with the activity of zygote formation. After egg shell damaging process, the next process is tissue damaging, these process causing many eggs die before hatching in treatment E. Similarly, by treatment with a lower dose of enzyme solution, the outer layer of the eggshell (chorion) is not damaged, but the lack of dose also slows the hatching process so that the egg undergoes lysis before hatching because it takes too long in the aerated hatching medium. According to Haser, et al. (2018) giving large concentrations will cause damage to the enzyme so that the work of the hatching enzyme is disrupted which can hinder the process of hatching eggs so that it causes abnormalities in fish larvae.

Survival rate is the percentage of the number of larvae which still live at the end of the study. Calculation of the number of live larvae is done after the egg yolk runs out. The time needed is 7 days. During maintenance no feeding is done because the larvae can take nutrients from the yolk. Research data can be seen in table 2 . 
Table 2 - O. niloticus larvae survival rate

\begin{tabular}{|c|c|c|c|c|c|c|}
\hline \multirow{2}{*}{ Enzyme } & \multirow{2}{*}{$\begin{array}{c}\text { Dose } \\
\text { (micromole) }\end{array}$} & \multicolumn{3}{|c|}{ Replication } & \multirow[b]{2}{*}{ Total } & \multirow[b]{2}{*}{ Average } \\
\hline & & 1 & 2 & 3 & & \\
\hline \multirow{3}{*}{ Papain } & 0.12 & 100 & 76.47 & 47.05 & 223.52 & 74.51 \\
\hline & 0.15 & 95.45 & 76.47 & 64.75 & 236.67 & 78.89 \\
\hline & 0.18 & 53.33 & 63.15 & 93.75 & 210.23 & 70.08 \\
\hline \multirow{3}{*}{ Bromelain } & 0.12 & 89.47 & 72.72 & 80.95 & 243.14 & 81.05 \\
\hline & 0.15 & 75 & 81.82 & 83.33 & 240.15 & 80.05 \\
\hline & 0.18 & 83.33 & 94.17 & 83.33 & 260.83 & 86.94 \\
\hline Total & & & & & 1414.54 & \\
\hline
\end{tabular}

Table 2 depicted that the treatment of the addition of the enzyme papain gets the highest average results in the treatment with a dose of 0.15 of $78.89 \%$. The treatment that gets the lowest average results $(70.08 \%)$ is at 0.18 micromoles. As for the addition of the bromelain enzyme treatment, the highest average $86.94 \%$ was in the treatment with a dose of 0.18 and the lowest average results is at 0.15 treatment at $80.05 \%$. Based on table 2 can be presented a graph of the average survival rate of tilapia eggs on media containing the enzymes papain and bromelain with different dosage contained in Figure 2.

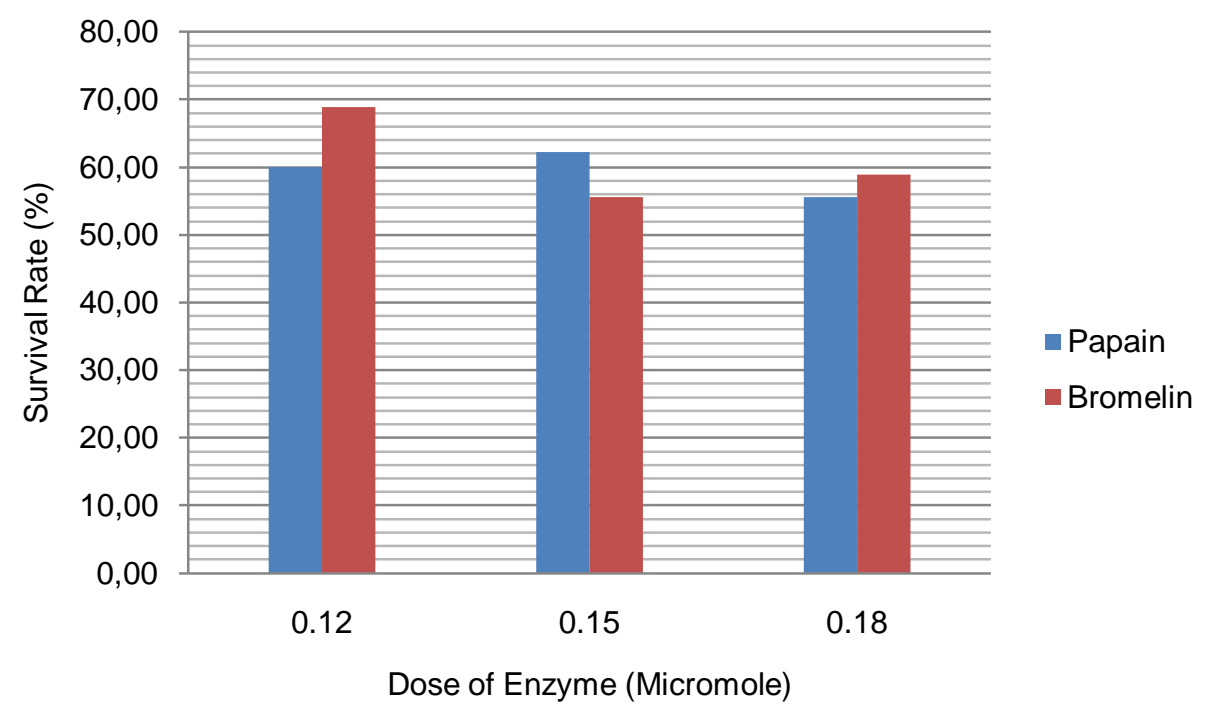

Figure 2 - O.niloticus larva survival rate graph

The survival rate data of tilapia larvae obtained were analyzed using a variance test. This was done to determine the effect of different enzymes and dosage on the survival rate of fish larvae. Based on the calculations, the results obtained $f$ count value $<f 5$ and $f 1 \%$ so it can be concluded that administration of different enzymes and dosage does not affect the survival rate of tilapia larvae. This is consistent with the statement of Saputra et al. (2012), that the administration of pineapple solution did not affect the survival of larvae. According to Saputa et al. (2014), factors that affect the survival rate of an organism include competition between species, lack of food, parasites and the ability to adapt to the environment. The survival rate of fish is high if the quality and quantity of feed and the environment are supportive.

\section{CONCLUSION}

The results showed that the highest hatching success rate using the papain enzyme was obtained at a dose of 0.15 micromole of $73.33 \%$, whereas when using the bromelain enzyme at a dose of 0.12 micromole of $68.89 \%$. Tilapia eggs can hatch faster than tilapia eggs without treatment. The highest survival rate using the papain enzyme was obtained at a 
dose of 0.15 with a value of $78.89 \%$ while those using the bromelain enzyme were obtained at a dose of 0.12 of $86.94 \%$.

Referring to the results of research conducted, so to enhance up the recovery process of the parent $O$. niloticus, farmers can hatch outside the mother's mouth by using the enzymes papain and bromelain.

\section{REFERENCES}

1. Aliyas S.N., Ya'la, 2016. Pertumbuhan and kelangsungan hidup ikan nila (Oreochromis sp.) yang dipelihara pada media bersalinitas. Jurnal Sains and Teknologi Tadulako 5(1) 19-27.

2. Ghufran M H and K Kordi 2010 Panduan Lengkap Budidaya Ikan Air Tawar di Kolam Terpal. (Yogyakarta - Lily Publisher) 280.

3. Cyntya V A, G W Santosa E. Supriyantini and S Y Wulandari 2018 Pertumbuhan rumput laut Gracilaria $\mathrm{sp}$ dengan rasio N:P yang berbeda Journal of Tropical Marine Science 1(1) 15-2.

4. Effendi, M. I. 2002 Biologi Perikanan (Yogyakarta - Yayasan Pustaka Nusatama) 163.

5. Hamza, 2017. Bacterial Protease Enzyme: Safe and Good Alternative for Industrial and Commercial Use. International Journal of Chemical and Biomolecular Science 3(1) 1-10.

6. Haser, T.F., S. P. Febri., and M.S. Nurdin. 2018. Efektifitas Ekstrak Daun Pepaya Dalam Menunjang Keberhasilan Penetasan Telur Ikan Bandeng (Chanos chanos Forskall). Jurnal Agroqua. 16(2): 92-99.

7. Kayhan, Figen Esin and Belgin Süsleyici Duman (2010). Heat Shock Protein Genes in Fish. Turkish Journal of Fisheries and Aquatic Sciences 10: 287-293

8. Iskandar $\mathrm{R}$ and Elrifadah 2015 Pertumbuhan and efisiensi pakan ikan nila (Oreochromis niloticus) yang diberi pakan buatan berbasis kiambang Ziraa'ah 40(1) 18-24

9. Kossakowski, Michael K. 2012. Fish hatching strategies. A review. Fish Biology and Fisheries 22(1). DOI: 10.1007/s11160-011-9233-7

10. Larasati S, F Basuki and T Yniarti 2017 Pengaruh jus nanas dengan konsentrasi berbeda terhadap derajat pembuahan and penetasan telur ikan patin (Pangasius pangasius) Journal of Aquaculture Management and Technology 6 (4) 218-225.

11. Linhart O, Gela D, Flajshans M, and Rodina M 2003 proteolytic enzyme treatment: an improved method for elimination of egg stickiness in tench, tinca tinca In Aquaculture Journal Appl. Ichthyol 1(9) 134-137.

12. Masniar M, Muchlisin, Karina, 2016. Pengaruh penambahan ekstrak batang nanas pada pakan terhadap laju pertumbuhan and daya cerna protein pakan ikan betok (Anabas testudineus) Jurnal IImiah Mahasiswa Kelautan and Perikanan Unsyiah 1(1) 35-45.

13. Mukti, A.T., Arsianingtyas, H., and Subekti, S. 2009. Pengaruh Kejutan Suhu Panas and Lama Waktu Setelah Pembuahan Terhadap Daya Tetas and Abnormalitas Larva Ikan Nila (Oreochromis niloticus). Jurnal Ilmiah Perikanan and Kelautan. 1(2): 163-168.

14. Santoso 1996 Budidaya Ikan Nila (Yogyakarta- Kanisius publisher) 135.

15. Saputra E E, H Alwi and Nuraini 2012 Pengaruh Dosis Larutan Nenas terhadap Daya Rekat (Adhesiveness) and Penetasan Telur Ikan Lele Dumbo (Clarias gariepinus Burchell) 3(2) 56-67.

16. Soviawati, E. 2004. Pengaruh Kejutan Suhu Panas (Heat Shock) Terhadap Derajat Penetasan Telur (Hatching Rate) and Kelulusan Hidupan (Survival Rate) Larva Ikan Mas (Cyprinus Carpio) Pada Proses Androgenesis Mitosis, Skripsi, Universitas Jember, Program Studi Pendidikan Biologi, Jurusan Matematika and IImu Pengetahuan Alam. 